\title{
Towards the science of managing for innovation: the beginning
}

\author{
Anne-Laure Mention \\ anne-laure.mention@rmit.edu.au | RMIT University, Australia \\ João José Pinto Ferreira \\ jjpf@fe.up.pt | INESC Technology and Science, Faculty of Engineering, University of Porto, Portugal \\ Marko Torkkeli \\ marko.torkkeli@lut.fi | Lappeenranta University of Technology, Finland
}

Some might argue that ever so nimble and responsive innovation paradigms can rarely be managed scientifically. We propose a more inclusive perspective. Science of managing for innovation has certain characteristics which we identify through the acronym "ROTRUS"- Real world, Observable, Testable, Replicable, Uncertain and Social. Real world refers to the notion that innovation happens in practical settings, be bound by resources and capabilities. This real world is the context in which the observable events occur. To progress the understanding of formative predictors and their impact on innovation, the innovation events need to be observable. This may be challenging if we are to believe that much of the innovation is driven by heuristics (see e.g. Lopez-Vega, Tell and Vanhaverbeke, 2016; Nisch and Veer, 2018). Observable evidence in our perspective does not mean it needs to be capable of being observed but includes events or phenomenon that were observed. In this sense, managerial heuristics once actioned become observed evidence, such that observable evidence is any evidence that can be or has been experienced by one or many, regardless of whether this can be observed by a third party. Yet, to progress further as science, these observations need to be replicable, and in the least predictable. Here innovation connects with psychology. Decades of psychology research and the recent works (see e.g. psychology of innovation by Cropley and Cropley, 2015 and cognition and innovation by Sund, Galavan and Brusoni, 2018) have shown us one thing - human behaviour is predictable under given conditions, and hence can be manipulated (Ariely, 2009). Given that humans are at the centre of all innovations (be as creator or user), this emphasises the current focus on humans in advancing the science of managing for innovation, both in terms of innovation as a process and an outcome (see Butler and Roberto, 2018; Yang, Wang, Zhou and Jiang, 2018). While this focus on how individual and group cognitive processes is recent and ongoing, it is likely to lead to scientific theories only when it can be repeated and proved or disproved. As evidence builds, science of managing for innovation will become more predictable. Yet, we must remain 
cautioned that it will never be $100 \%$ correct. This is especially the case when events involve social factors. As innovation continues to be more open and collaborative (Bogers, Chesbrough and Moedas, 2018), human social interactions within and between firms are becoming part of business-as-usual, explained in innovation literature through concepts of coopetition and cooperation (Bouncken, Fredrich, Ritala and Kraus, 2018; Mention, 2011). It is imperative in times like these that the focus is on the 'whole' rather than any singular nuances. Perhaps, because such a perspective also considers what is happening across various individual and group psychological levels as well as the interactions at organisational, ecosystem and global-level.

We argue that relying on single case studies or methods that draw on point-in-time beliefs, attitudes and perceptions of select individuals while interesting, pose a challenge for replicability. To move towards the science of managing for innovation, we need to be careful in avoiding pseudoscience and drawing generalised assumptions from information that is still in the proto-science stage (early understanding). Concentrating on single case studies (see recent innovation stories e.g. Manzini, Lazzarotti and Pellegrini, 2017) is like trying to understand complex brain functioning by focusing on select few neurons, when common knowledge tells us that brain functions through connectivity. In innovation management terms, literature is increasingly drawing attention to so-called failed cases (Ciesielska, 2018; von Briel and Recker, 2017) or 'sleeping beauties' (e.g. Dabrowska, Lopez-Vega and Ritala, 2019) in trying to draw prescriptions on the ways of managing for innovation. Yet, in keeping with the brain analogy, ask a neurologist, they will tell you that a focus on 'damaged' cells is less likely to reveal how to manage the brain functionality, compared to a focus on the science of how new connections are formed, stimulated and recognised. Even when there are fully functioning neurons in one area of the brain it bears little importance unless the firing of such neuron triggers interconnected transfer of a series of action potentials down the axon to result in desired reaction (electrical impulse transfer across the nerve in simpler terms). So, when the objective is to understand the formative predictors of innovation, at an individual level the focus needs to be on not only the mental processes but also the deeper neurological events affecting it and the behavioural outcomes arising from such processes. At a group or societal level, this means even when a firm has a 'cognitively present' manager, that individual insight has limited relevance to innovation, unless the cognitive flexibility and adaptability is shared amongst all those tasked to bring innovation to fruition. Science of managing for innovation, in this respect, calls for observation of not only individual-level predictors of innovation process and outcome, but also the interaction mechanisms that translate individual motivations and perceptions into intentions and socially-motivated behaviour.

In the following section, the beginning, we briefly introduce the foundations that can plausibly serve as levels of inquiry. As the reader will notice, some levels are obvious and well-researched where others are not. We do not intend to state this obvious, rather we aim to highlight the interconnectivity across levels and emphasis the need to investigate the interactions across levels to build replicable evidence to advance the science of managing for innovation. 


\section{The Beginning}

\section{I think, therefore I am. - René Descartes}

Long ago, the ancient Greeks viewed brain as important part of the sacred human body. It was the early works of Pythagorean Alcmeon of Croton in the 6th and 5th centuries BC that we recognised the centrality of the brain and its connections to the mind. Nevertheless, it was not until Descartes in the 17th century famously argued the then illusive link between brain (I think) and mind (I am), that the discourse became disparate from the belief that brain was just an organ that cooled the body (Bear, Connors and Paradiso, 2001). In his famous work, the Mediations on First Philosophy (1641), Descartes formed association of mind with that of "a thing that thinks" and body as its "extension" (Descartes 1637/1980, 93). This formative assumption that it is the interactions of brain and mind that affects human behaviour has profoundly influenced the way we understand the world. More recent work in neuroplasticity has suggested that cognition and alterations to cognition through training regimes could affect the brain structure (Green and Bavelier, 2008). From an innovation management perspective, this notion attempts to explain the adaptive capacity of humans to learn new skills and cope with new knowledge sharing environments. However, it complicates the previous simplified depiction of the linear relationship between brain, mind and behaviour, spanning multiple levels of analysis. Our primary objective in this editorial is to re-imagine these levels of analysis as not hierarchical but interconnected stages (Fig. 1) and thus as an important segue towards the science of managing for innovation. The neurological level represents the 'the brain' and the biological factors such as genetic formations, brain chemical messengers and intelligence (Ilardi and Feldman, 2001). The mental level represents the 'the mind' and the behavioral level captures the actions, exchanges and effects of social interactions (Lilienfeld et al., 2016).

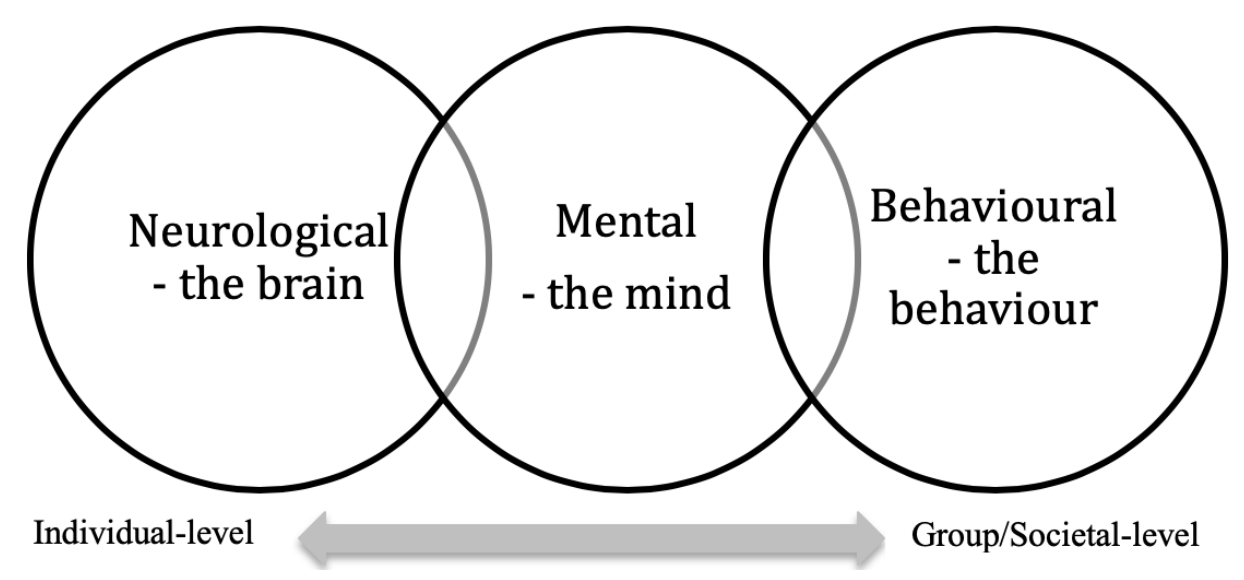

Fig. 1. Levels of analysis for science of managing for innovation (Source: Adapted from Lilienfeld et al., 2018)

The brain being the intelligence center of the body with neurons as its core functional units, implicates cognition, perception, emotions, feelings and sensitivity through transmission of action potential (firing of the neurons) (Lilienfeld et al., 2016). While some research points to the relationship between firing of a neuron and behavioural conditioning (Tsai et al., 2009), including 
motivated goal-oriented behaviour (Grace et al., 2007), there is limited understanding on the links between brain activation and cognition (Lauriero-Martinez, Brusoni and Zollo, 2010). Some views in neuroscience exploring effects of social conditions (e.g. social exclusion) on patterns of brain activation through fMRI suggest that there may be significant correlates between what the mind think, what the body feels and how the brain reacts (Eisenberger, Lieberman, and Williams, 2003). This opens a new stream of investigations investigating the neurological effects on innovate on processes and outcomes.

From a management perspective, scholars in recent times have recognised the interplay of these multiple levels of analysis from various vantage points (see e.g. Narayanan, Zane, and Kemmerer 2011). The 'mind' in particular has been studied extensively in management literature (see e.g. Abell, Felin and Foss, 2008; Grisold and Peschl 2017). Much of the research in this stream has focused on knowledge, perceptions, cognition, thinking, emotions and feelings, often keeping to the boundaries of subjective-objective dichotomy. Some focus has been on the human behavioural aspect of innovation management (Salampasis and Mention 2017), albeit largely confined to attitudes (e.g. Antons and Piller 2015), cognitive coping (Salter, Criscuolo, \& Ter Wal, 2014) and individual characteristics (Bogers, Foss and Lyngsie, 2018), with infrequent studies linking genetic hereditary to risk-taking behaviour (Shikishima et al. 2015; Zuckerman and Kuhlman 2000). While these studies might just have triggered a renewed focus on the human factors in innovation management, we propose that to advance the science of managing for innovation, research needs to focus on the 'whole' and argue that scientific revelations are more likely to emerge from studies that explore, explain and predict the peculiarities of the brain-mind-behaviour triad.

In the next editorial, we will progress the beginning introduced here to interim discussions on the science of managing for innovation with a focus on innovation problems and research methods before finally arriving at the conclusion and propositions for the future of innovation management research and practice. Meanwhile, we welcome your conceptual, theoretical, perspective and empirical contributions on topics that relate to innovation and its management.

Innovatively yours,

Anne-Laure Mention, João José Pinto Ferreira, Marko Torkkeli

The Editors

\section{References}

Abell, P., Felin, T. and Foss, N., 2008. "Building micro-foundations for the routines, capabilities, and performance links." Managerial and decision economics, 29(6): 489-502.

Antons, D. and Piller, F.T., 2015. "Opening the black box of "Not Invented Here": Attitudes, decision biases, and behavioral consequences." The Academy of Management Perspectives, 29(2): 193-217.

Ariely, D., 2009. "Predictably irrational", revised and expanded edition. HarperCollingsPublishers, London. 
Bear, M.F., Connors, B. W., and Paradiso M.A. 2001. "Neuroscience: Exploring the Brain." Baltimore: Lippincott.

Bogers, M., Chesbrough, H. and Moedas, C., 2018. Open innovation: research, practices, and policies. California Management Review, 60(2), pp.5-16.

Bogers, M., Foss, N.J. and Lyngsie, J., 2018. The "human side" of open innovation: The role of employee diversity in firm-level openness. Research Policy, 47(1), pp.218-231.

Bouncken, R.B., Fredrich, V., Ritala, P. and Kraus, S., 2018. Coopetition in new product development alliances: advantages and tensions for incremental and radical innovation. British Journal of Management, 29(3), pp.391-410.

Butler, A.G. and Roberto, M.A., 2018. When Cognition Interferes with Innovation: Overcoming Cognitive Obstacles to Design Thinking: Design thinking can fail when cognitive obstacles interfere; appropriate cognitive countermeasures can help disarm the traps. Research-Technology Management, 61(4), pp.45-51.

Chesbrough, H.W., 2003. Open innovation: The new imperative for creating and profiting from technology. Harvard Business Press.

Ciesielska, M., 2018. Nokia on the slope: The failure of a hybrid open/closed source model. The International Journal of Entrepreneurship and Innovation, 19(3), pp.218-225.

Cropley, D.H. and Cropley, A.J., 2015. The psychology of innovation in organizations. Cambridge University Press.

Dąbrowska, J., Lopez-Vega, H. and Ritala, P., 2019. Waking the sleeping beauty: Swarovski's open innovation journey. RED Management.

Descartes, R. (1637/1980). Discourse on the method for rightly conducting one's reason and for seeking truth in the sciences. In D. A. Cress (Ed.), Discourse on method and meditations on first philosophy. Indianapolis, IA: Hackett Publishing Company.

Eisenberger, N.I., Lieberman, M.D. and Williams, K.D., 2003. "Does rejection hurt? An fMRI study of social exclusion." Science, 302(5643): 290-292.

Grace, A.A., Floresco, S.B., Goto, Y. and Lodge, D.J., 2007. "Regulation of firing of dopaminergic neurons and control of goal-directed behaviors." Trends in neurosciences, 30(5): 220-227.

Green, C.S. and Bavelier, D., 2008. "Exercising your brain: a review of human brain plasticity and training-induced learning." Psychology and aging, 23(4): 692.

Grisold, T. and Peschl, M., 2017. "Organizational Predictive Mind as Obstacle for Change and Innovation: A Systems Thinking Perspective." Marketing and Innovation Strategies for Small and Medium-sized Enterprises (SMEs): 70.

Ilardi, S.S. and Feldman, D., 2001. "The cognitive neuroscience paradigm: A unifying metatheoretical framework for the science and practice of clinical psychology." Journal of Clinical Psychology, 57(9): 1067-1088.

Laureiro-Martínez, D., Brusoni, S. and Zollo, M., 2010. The neuroscientific foundations of the exploration- exploitation dilemma. Journal of Neuroscience, Psychology, and Economics, 3(2), p.95. 
Lilienfeld, S., Lynn, S.J., Namy, L., Woolf, N., Jamieson, G., Marks, A. and Slaughter, V., 2016. "Psychology: From inquiry to understanding (Vol. 2)." Australia: Pearson Higher Education.

Lopez-Vega, H., Tell, F. and Vanhaverbeke, W., 2016. Where and how to search? Search paths in open innovation. Research Policy, 45(1), pp.125-136.

Manzini, R., Lazzarotti, V. and Pellegrini, L., 2017. How to remain as closed as possible in the open innovation era: the case of Lindt \& Sprüngli. Long Range Planning, 50(2), pp.260-281.

Mention, A.L., 2011. Co-operation and co-opetition as open innovation practices in the service sector: which influence on innovation novelty?. Technovation, 31(1), pp.44-53.

Narayanan, V.K., Zane, L.J. and Kemmerer, B., 2011. "The cognitive perspective in strategy: An integrative review." Journal of Management, 37(1): 305-351.

Nisch, M. and Veer, T.H., 2018, July. The Role Of Heuristics In Innovation Project Selection. In Academy of Management Proceedings (Vol. 2018, No. 1, p. 14106). Briarcliff Manor, NY 10510: Academy of Management.

Salampasis, D. and Mention, A.L., 2017. "Open Innovation: Unveiling the Power of the Human Element." Singapore: World Scientific Publishing.

Salter, A., Criscuolo, P. and Ter Wal, A.L., 2014. "Coping with open innovation: responding to the challenges of external engagement in R\&D." California Management Review, 56(2): 7794.

Shikishima, C., Hiraishi, K., Yamagata, S., Ando, J. and Okada, M., 2015. "Genetic factors of individual differences in decision making in economic behavior: A Japanese twin study using the allais problem." Frontiers in psychology, 6: 1712.

Sund, K.J., Galavan, R.J. and Brusoni, S. eds., 2018. Cognition and innovation. Emerald Publishing Limited.

Tsai, H.C., Zhang, F., Adamantidis, A., Stuber, G.D., Bonci, A., De Lecea, L. and Deisseroth, K., 2009. "Phasic firing in dopaminergic neurons is sufficient for behavioral conditioning." Science, 324(5930): 1080-1084.

von Briel, F. and Recker, J.C., 2017. Lessons from a failed implementation of an online open innovation community in an innovative organization. MIS Quarterly Executive, 16(1), pp.3546.

Yang, D., Wang, A.X., Zhou, K.Z. and Jiang, W., 2018. Environmental strategy, institutional force, and innovation capability: A managerial cognition perspective. Journal of Business Ethics, pp.1-15.

Zuckerman, M. and Kuhlman, D.M., 2000. "Personality and risk-taking: common bisocial factors." Journal of personality, 68(6): 999-1029.

Cite paper as: Mention, A., Pinto Ferreira, J.J., Torkkeli, M., (2019). Towards the science of managing for innovation: the beginning, Journal of Innovation Management, www.open-jim.org, 7(2), 1-6. 